International Journal of Innovative Research in

Electrical, Electronics, Instrumentation and Control Engineering

Vol. 9, Issue 10, October 2021

DOI: 10.17148/IJIREEICE.2021.91008

\title{
FABRICATION OF E-BIKE USING LITHIUM ION BATTERY WITH REGENERATIVE BRAKING SYSTEM
}

\author{
Dr. Suresh C ${ }^{1}$, S. B. Arjun Dhilip ${ }^{2}$, Alan Johnson ${ }^{3}$,Aravinth Kumar ${ }^{4}$, S. Gowtham ${ }^{5}$ \\ ${ }^{1}$ Assistant Professor in ACS College of Engineering, Bengaluru. \\ ${ }^{2,3,4,5}$ Student in Dept. of Aeronautical Engineering, Hindusthan College of Engineering and Technology, \\ Coimbatore, Tamilnadu, India.
}

\begin{abstract}
In this paper, we are concerning about the growing demand of energy all over the world, which motivated us to switch over renewable resource of energy. There are many different ways by which we can save energy in different sectors. Our main focus is on automobile sector where we are converting old petroleum bike to electric bike. In this electric bike we use electrical motor (BLDC hub motor) instead of combustion engine as it emits less pollution, low maintenance cost, reduces noise. This bike utilizes chemical energy stored in the rechargeable battery packs. This paper deals with the design and development of electric bike which makes use of electric energy as primary source. There is a distribution for charging the battery emitting it from the main system.
\end{abstract}

Key words: electric vehicle, BLDC hub motor, electric bike, lithium-ion battery.

\section{INTRODUCTION:}

The main reason to design the electric bike is to overcome the problem with the pollution and with the economy. Future E bike is the best technical application as a solution for the better world and upcoming generation. The E-bike is a battery operated vehicle that is very economical with low maintenance cost and less pollution. E bikes are an attractive alternative to both conventional motorcycles and traditional automobiles, providing an environmentally friendly, fun, efficient and convenient way to travel. Also the battery can be recharged with the help of Regenerative braking system.

E- Bike is the plug-in electrical vehicles with two wheels. The power on which this bike works is stored in a rechargeable battery which drives the motor. Now a days these bikes are manufactured at a very large scale. Typical parts used in Ebike are BLDC motor, battery, controller, throttle, DC-DC converter, speed controller etc. So, combining both issues, environmental progress supporting and economical wise, affordable alternative would be the best solution.

\section{CONSTRUCTION AND METHODOLOGY:}

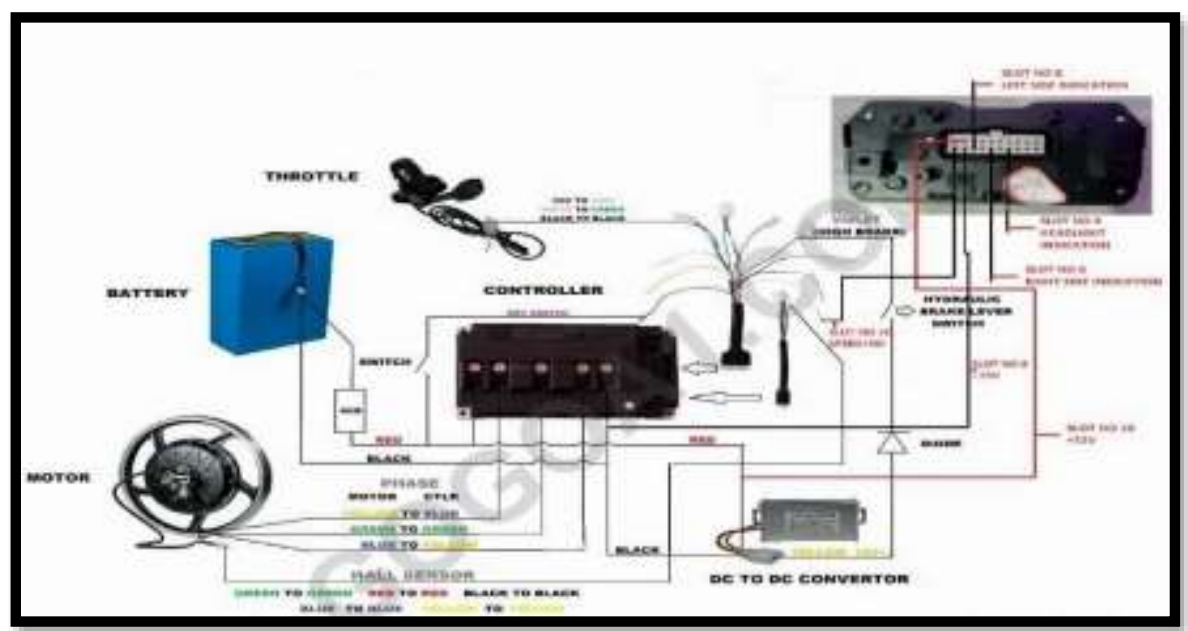


International Journal of Innovative Research in

Electrical, Electronics, Instrumentation and Control Engineering

Vol. 9, Issue 10, October 2021

DOI: 10.17148/IJIREEICE.2021.91008

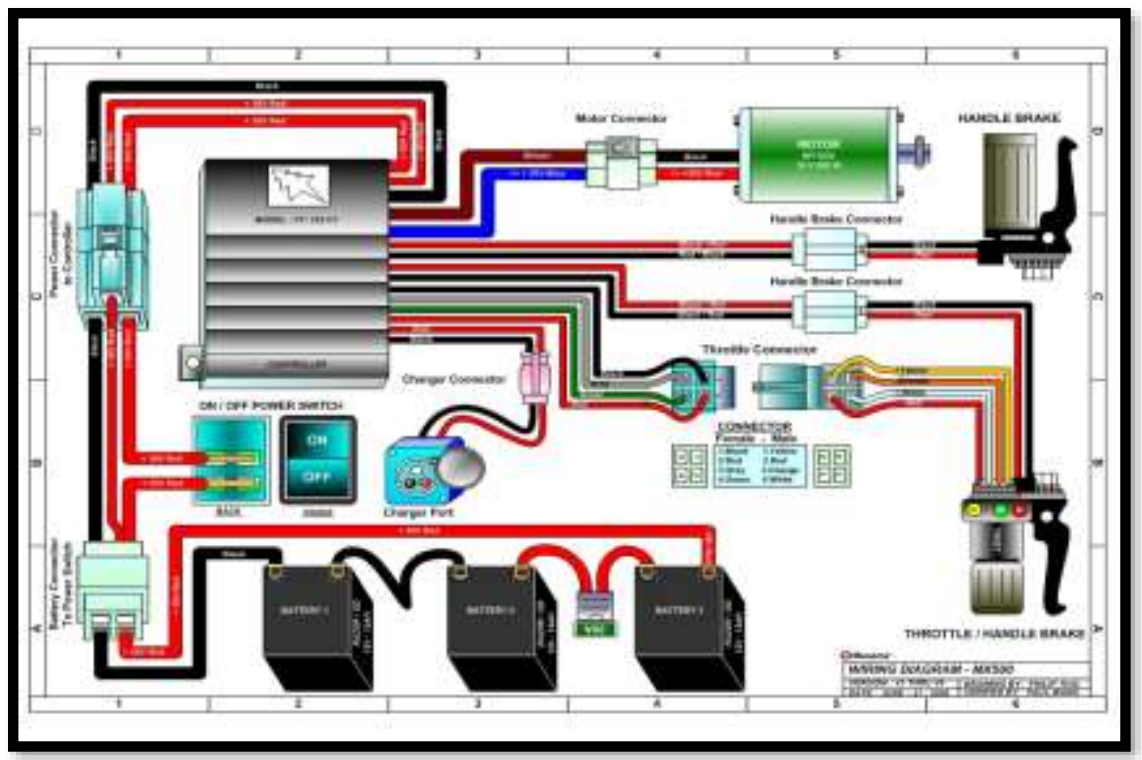

E-bike Specifications:

\begin{tabular}{|l|l|}
\hline Seat Height & $785 \mathrm{~mm}$ \\
\hline Ground Clearance & $159 \mathrm{~mm}$ \\
\hline Wheel Base & $1236 \mathrm{~mm}$ \\
\hline Overall Length & $1970 \mathrm{~mm}$ \\
\hline Overall Width & $720 \mathrm{~mm}$ \\
\hline Overall Height & $1040 \mathrm{~mm}$ \\
\hline Wheel Lock Angle & $20^{\circ}$ \\
\hline Tyre Radius & $316 \mathrm{~mm}$ \\
\hline RPM & $1000 \mathrm{rpm}$ (Average of 900 \& 1100) \\
\hline
\end{tabular}

1. Speed calculation formula:

Converting rpm in to linear velocity

$\mathrm{V}=2 * 3.14 * \mathrm{R} * \mathrm{RPM} * 60 / 1000$

$\mathrm{V}=$ targeted speed $\mathrm{km} / \mathrm{hr}$

$\mathrm{R}=$ radius of wheel in $(\mathrm{m})$

$\mathrm{V}=2 * 3.14 * 0.316 * 1000 * 60 / 1000$

$\mathrm{V}=119.06 \mathrm{~km} / \mathrm{hr}$

2. Turning radius

Turning radius $=2 \times($ wheel base $) \times \operatorname{Sin}\left(90^{\circ}\right.$-wheel lock angle $)$

$$
\begin{aligned}
& =2 \times 1236 \times \sin \left(90^{\circ}-20^{\circ}\right) \\
& =2322.92 \mathrm{~mm}
\end{aligned}
$$

\section{Leaning angle}

Leaning angle $(\alpha)=\tan ^{\wedge}-1\left(v^{\wedge} 2 / \mathrm{r} \mathrm{x} \mathrm{g}\right)$

Where, $\alpha=$ Leaning Angle;

$\mathrm{r}=$ Turning Radius

$\mathrm{g}=$ Acceleration Due To Gravity

$\alpha=[\tan -1(20 \times 20 \times 0.277 \times 0.277)] /$ [2. $x$ 9.81]

$\alpha=53.910$ 


\section{International Journal of Innovative Research in \\ Electrical, Electronics, Instrumentation and Control Engineering}

Vol. 9, Issue 10, October 2021

DOI: 10.17148/IJIREEICE.2021.91008

4. Angular velocity

Angular velocity $(\omega)=2 \pi \mathrm{n} / 60=0.1047 * 900$

Angular velocity $(\omega)=104.7 \mathrm{rad} / \mathrm{s}$

\begin{tabular}{|c|c|}
\hline \multicolumn{2}{|c|}{ Design and Calculation of Electrically driven Motorcycle: } \\
\hline \multicolumn{2}{|c|}{ Power calculation of Hub motor (17 inch 2000 W) } \\
\hline Operating voltage: & $72 \mathrm{~V}$ \\
\hline Rated Current : & $100 \mathrm{~A}$ \\
\hline Maximum Speed: & $100 \mathrm{~km} / \mathrm{h}$ \\
\hline To run $2 \mathrm{~kW}$ for 1 hour: & $2000 \mathrm{~W} * 1 \mathrm{hr}=2000 \mathrm{Watt} \mathrm{hr}$ \\
\hline $\begin{array}{l}\text { For } 80 \% \text { efficiency of } \\
\text { battery: }\end{array}$ & $2000 / 0.8=2500 \mathrm{Watt}$ hr \\
\hline $\begin{array}{l}\text { Current to be passed for } \\
1 \text { hour for } 2 \mathrm{kw} \text { motor: }\end{array}$ & $\begin{array}{l}\text { Watt hr= Voltage } * \text { Ampere hr } \\
2000=72 * \text { Ah } \\
2000 / 72=27.7 \mathrm{Ah}\end{array}$ \\
\hline Weight of the Bike: & W1=60 kg (Average) \\
\hline Weight of the Rider: & $\mathrm{W} 2=100 \mathrm{~kg}($ Average $)$ \\
\hline $\begin{array}{l}\text { Normal reaction on each } \\
\text { tyre: }\end{array}$ & $\begin{array}{l}\mathrm{N}=(\mathrm{W} 1+\mathrm{W} 2) / 2=160 / 2=80 \mathrm{~kg} \\
80 * 9.81=784.8 \mathrm{~N}\end{array}$ \\
\hline $\begin{array}{l}\text { Friction force on each } \\
\text { tyre: }\end{array}$ & $\mathrm{F}=\mathrm{u} * \mathrm{~N}=0.3 * 784.8=235.44 \mathrm{~N}$ \\
\hline Torque Requirement: & $\mathrm{T}=\mathrm{F} * \mathrm{r}=235.44 * 0.316=74.3 \mathrm{Nm}$ \\
\hline \multicolumn{2}{|c|}{ 2. $\quad$ Battery equations and calculations $(72 \mathrm{~V}, 30 \mathrm{Ah}),(\mathrm{Li}$-ion) } \\
\hline Weight: & $9.405 \mathrm{~kg}$ \\
\hline Size: & $361 \mathrm{~mm} * 209 \mathrm{~mm} * 85 \mathrm{~mm}$ \\
\hline Power: & $\begin{array}{l}\text { Power }=\text { Voltage } * \text { Current } \\
2000=72 * \mathrm{I} \\
\mathrm{I}=27.78 \mathrm{~A} \text { (Theoretical) } \\
\text { (Average }=30 \mathrm{~A})\end{array}$ \\
\hline Total Capacity: & $\begin{array}{l}72 * 30=2160 \text { Watt } \\
2160 \text { Watt for } 1 \text { hour }=2160 \text { Watt hour }\end{array}$ \\
\hline
\end{tabular}

PHASE 1: Planning of E-Bike and its design layout

A Design layout of the entire bike is planned accordingly, including all its components, arrangement, fabrication and more. This includes buying a old used bike, and disassembling all the parts and making the frame more suitable for Ebike fabrication. The planning of the E-bike and laying out its design is completed when all the components are selected and bought and tested. If the components seem to malfunction or is not appropriate for that particular design it has to be replaced immediately.

\section{PHASE 2: Assembling of all the components}

All the components were collected and assembled appropriately according to the specifications. This is done carefully such that there is no incorrect connection which can cause short in the circuit. Firstly the hub motor is attached with the rear wheel for producing thrust on that wheel and hence rotating it. The hub motor is placed in the rear wheel because of stability and comfort in riding. It is connected with disc brake and for betterment and safety during riding due to its effectiveness.

Next the battery is fitted on the part where the engine is placed in an conventional bike. On top of the battery the speed controller and DC_DC converter is placed. The MCB switch is placed just adjacent to it. The throttle and brakes are fitted on the handle bars of the bike. The speedometer is placed between the handle bars. For the rider and the passenger sitting on the bike the seat is also placed in a conventional way.

\section{PHASE 3: Fabrication completion}

The 3 different views of the bike has been spotted above. The fabrication of the E-Bike has been successfully completed including all its components. The wheels has been fitted and front shock absorbers has been cleaned and oiled. The seat 


\section{International Journal of Innovative Research in \\ Electrical, Electronics, Instrumentation and Control Engineering}

Vol. 9, Issue 10, October 2021

\section{DOI: $10.17148 /$ IJIREEICE.2021.91008}

supporters has been fitted for the comfort. The wires have been placed carefully and the battery charger has been placed in the petrol tank space of the bike. So now the bike is absolutely equipped and ready for riding.

\section{PHASE 4: Final Testing of the E-Bike}

The E-Bike's test riding has been completed successfully, and there is no sign of any kind of fault in the wiring or the assembly of all the components, nor there is any proof for the unfit condition of the bike. All the components have been separately tested and has also been tested when it has assembled together appropriately. The result of the test ride appeared to be positive and successful.

\section{CONCLUSION}

Electric vehicles are the future of our world. There are alternative ways by which we can save energy. With the increasing consumption of natural resources of petrol, diesel it is necessary to shift our way towards alternate resources like the Electric bike and others because it is necessary to identify new way of transport. The most important feature is to be pollution free, eco - friendly and noiseless in operation. It is cheap source of transport and affordable to anyone. The motor used in this bike has high efficiency and the battery bank has less weight with high speed. These bikes are environmental friendly, needs less maintenance and can be also assembled to small component. The most important feature of this bike is that it does not consume valuable fossil fuels thereby saving ton of money for shipment of oil and fuel, thereby increasing our country's economy. People will start investing in electric vehicle companies and the shares will keep increasing rapidly.

\section{REFERENCE}

1. Fabrication of E-Bike by Mohammed Hassan Khan, Mohammed Habeeb Ullah Shareef, Mohd Faiz Ahmed - IRJET (International Research Journal of Engineering and Technology), 2020.

2. R\&D on Electric Bike by Yashwant Sharma, Praveen Banker, Yogesh Raikwar, Yogita Chauhan - IRJET, 2018.

3. Design and Fabrication of Electric Bike by Deep Prajapati, Kunjan Shinde, Abhishek Mhaske - IJMET (International Journal of Mechanical Engineering and Technology), 2017.

4. Next Generation Electric Bike by Pavan Reddy, Vishnu Prashant - ICPCSI (International Conference on Power, Control, Signals and Instrumentation Engineering), 2017.

5. A Visual Blindspot Monitoring System for Safe Lane Changes by Jamal Saboune, Mehdi Arezoomand, Luc Martel, Robert Laganiere Researchgate.net, 2014.

6. Study of Construction and Working of Hover Bike by Abhay Naware - IRJET, 2018. 